\title{
The contribution of Project Team Personal Competence to Sustainable Outcomes in Development Projects
}

\author{
, Jantanee Dumrak ${ }^{1 *}$, Sherif M ostafa², and Nick Hadjinicolaou ${ }^{1}$ \\ ${ }^{1}$ Global Project $M$ anagement, Torrens U niversity A ustralia, A ustralia \\ ${ }^{2}$ Construction and Engineering Project $M$ anagement, School of Engineering and Built Environment, \\ Griffith U niversity
}

\begin{abstract}
Projects are undertaken to serve the particular purposes of organizations. M any projects focus on having monetary benefits, but some projects are non-profit oriented and funded by international or national non-governmental organizations (NGOs) or donors to serve the development of communities. These funded projects are usually established in many disciplines including health, environment, economics, education, social and human rights in countries where the welfare of the population is deficient. From perspectives of project teams and sponsors, having a project-oriented approach allows more project control over their available resources and expected outcomes, especially long-term or sustainable outcomes. In this study, the term 'sustainable outcomes' refers to project activities and their outcomes that survive after the termination of external funding. Sustainable outcomes are derived from the maintenance of benefits generated from an initial project, the continuation of project activities within a new organization, and the maintenance of benefits realization. The sustainable outcomes are impacted by abilities to carry out both ongoing and long-term implementation. Therefore, it is important to ensure that personal competence in development projects contribute to sustainable outcomes. This study employs a correlation coefficient analyses to identify personal competence of project team members that contribute to achieving sustainable outcomes. Seventy-five respondents from development projects participated in the questionnaire survey. The research findings show that each of the sustainable outcome domain required different combinations of personal competence attributes.
\end{abstract}

Keywords: development projects, project management, personal competence, sustainable outcomes

\section{Introduction}

According to Bossert [1], sustainable outcomes within health development projects can be defined as any project that has expanded its funding yet the flow of benefits can be maintained for at least three years after the life of the project. According to Glasier et al. [2],

* Corresponding author: jantanee.d@gmail.com 
it is undeniable that many factors such as socio-cultural, political, economic and educational factors have direct impacts on the longevity of projects. These factors could make any health development projects and programs difficult to accomplish and maintain. The implementation of health improvement requires significant amounts of time, as well as other resources. Most development aspects are highly associated with a population's behavioural change and life cycle which are generally influenced by at least one of the factors mentioned above. Moreover, in some developing countries cultures such as those in Asia, the Middle East, and Africa, health issues are considered to be extremely personal, gender-related, and culturally sensitive issues.

In order to attain sustainable outcomes in health development projects, the barriers to desired outcomes must be mitigated. Many aspects related to sustainable outcomes have been discussed. One of the concerning aspects is to improve skills and personal competence of project officers [3]. To investigate personal competence in relation to sustainable outcomes of health development projects, this paper is structured into four sections. The next section is the literature review.

\section{Literature Review}

\subsection{Personal Competence}

Competency is defined as "an important trait of professionalism" [4]. Crawford [5, 6] spots a significant relationship between project management competence and organisational performance as well as the core elements of competences including knowledge, skills, attitudes and behaviours that lead to superior performance. The study is conducted on the ground that "if people who manage and work on projects are competent, they will perform effectively and that this will lead to successful projects and successful organisations"[6].

According to PMI [7], Project Manager Competency Development (PMCD) Framework is applied to direct individuals and organisations towards professional development in project management. The framework is designed incompatibility with the Guide to Project Management Body of Knowledge (PMBOK ${ }^{\circledR}$ Guide). Project management competence according to the PMCD Framework consists of three dimensions including knowledge, performance and personal competences. While knowledge competence focuses on project management credentials, performance and personal capability place their significance on technical and human performance skills as well as competent actions and behaviours in delivering and managing projects.

From the dimensions of competency, it can be said that an individual can be fully competent when he/she is able to integrate all three dimensions and deliver project performance that meets organisational expectations. The framework explains further that an individual competency assessment can be conducted by examining the level of knowledge and understanding of project management, ability to manage a project successfully, and the core personality characteristics that one is expected to possess in order to lead a project. The knowledge and performance competence exist in people-oriented professions, i.e. the selected project practitioners in this research, which can be explicitly presented within task descriptions and performance dashboards. Therefore, this paper only focuses on personal competence, an implicit dimension which is not commonly documented within projects.

\subsection{Sustainable Outcomes and Significance in Development Projects}

The term "sustainable outcomes" has been increasingly discussed among managers of development programs and projects. In development studies, terminologies including 
"sustainability" or "benefit sustainability" or "sustained benefits" or "sustainable benefits" have been used interchangeably to express sustainable outcomes. Benefits of sustainable outcomes can be seen from the study of Swidler and Watkins [8] that having sustainable outcomes, not only benefits from the optimization of project investment into the nation's population but also gains in knowledge and skills transfer in long-term perspectives. The concept of sustainable outcomes also includes the continuation of program activities within a new organization, the maintenance of initiatives by building community capacity, the maintenance of benefits generated from an initial program and the maintenance of program services for ongoing operations after the termination of funding and assistance from a donor $[9,10]$. Funding termination profoundly impacts on development projects especially when problems remain unsolved and require long-term implementation. With the concepts and application of sustainable outcomes, this could be one of the best solutions to ensure that the benefits and health interventions can be maintained [11-13]. Many research works have attempted to identify the impact of lacking sustainable outcomes to benefits and activities in development projects and programs when the major sponsoring agencies stop their funding $[1,8,9,14]$. Most of these studies found that benefits are generally discontinued after funding termination.

\section{Research Method}

Descriptive statistics employed in this data analysis presented project management background of 75 project practitioners who participated in the questionnaire survey (see Figure 1). The majority of the respondents had project experience of three years $(51.61 \%)$ and worked between $1-3$ projects $(79.03 \%)$ at the time the survey was conducted. The respondents who experienced project works for more than three years but less than five years were reported to be $27.42 \%$. Only $9.68 \%$ of this respondent group in this survey that delivered 4-5 projects during these years of experience. The respondents who had more seven years of project experience were counted to be $19.36 \%$ with different numbers of projects undertaken. Only $6.45 \%$ of these practitioners delivered 8 projects and over.

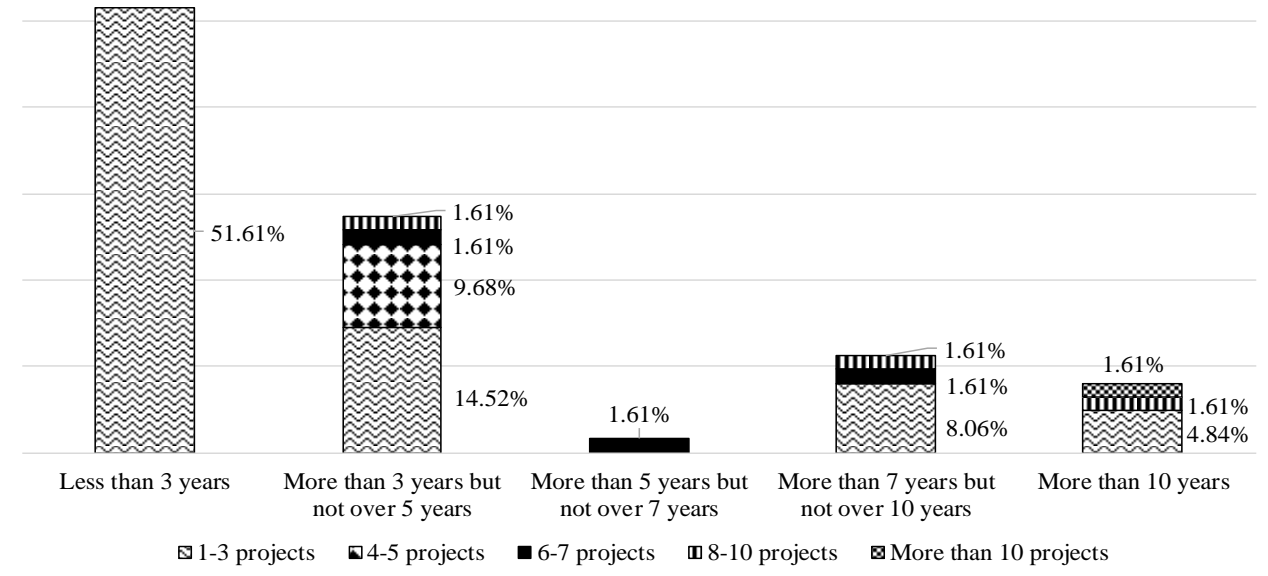

Fig. 4. Project Experience and N umbers of Projects Involved

The results of data analysis conducted using Spearman's Rho in Table 2 below show the directional relationships between attributes of personal competence and studied domains of 
sustainable outcomes. It was found that each of the sustainable outcome domain required different combinations of personal competence attributes.

At the sustainable outcome orientation where benefits realisation and knowledge are focused, all attributes, except Teamwork and Coordination, were chosen by the respondents as required attributes in this domain. According to the result, Task Organization $(r=.390$, $p<0.001)$ contains the strongest relationship to sustainable outcome orientation, followed by Self-confidence and Flexibility $(r=.385, p<0.001$ and $r=.380, p<0.001)$, respectively. In the domain of sustainable outcome capability building, not all attributes were related to this domain. The personal competence areas mostly associated with the sustainable outcome capacity building were Cognitive Ability and Effectiveness. Teamwork and Coordination has the strongest relationship $(r=.438, p<0.001)$, followed by Assertiveness $(r=.352, p<0.001)$. The last domain of sustainable outcome examination was sustainable outcome delivery. In this domain, it was found that the personal competence attributes associated with this domain were lesser than others, especially Leading which has none of the attributes significantly associated with sustainable outcome delivery. Amongst the associated attributes to this domain, Information Seeking forms the strongest relationship ( $r=$ $.391, p<0.001)$, followed by Flexibility $(r=.334, p<0.001)$ and Self-motivation $(r=.333$, $p<0.001)$.

Table 2. Spearman's Rho (r) Correlations between Personal Competence Attributes and Sustainable Outcome Domains

\begin{tabular}{|c|c|c|c|c|}
\hline $\begin{array}{l}\text { Personal } \\
\text { competence }\end{array}$ & Attribute & $\begin{array}{l}\text { Sustainable } \\
\text { outcome } \\
\text { orientation }\end{array}$ & $\begin{array}{l}\text { Sustainable } \\
\text { outcome } \\
\text { capability } \\
\text { building }\end{array}$ & $\begin{array}{l}\text { Sustainable } \\
\text { outcome } \\
\text { delivery }\end{array}$ \\
\hline \multirow{3}{*}{ Communication } & Interpersonal Understanding & $.359 * *$ & - & - \\
\hline & Information Seeking & $.326 * *$ & - & $.391 * *$ \\
\hline & Stakeholder Oriented & $.276^{*}$ & $.357 * *$ & $.267 *$ \\
\hline \multirow{4}{*}{ Leading } & Team Leading & $.302 *$ & - & - \\
\hline & Relationship Building & $.296^{*}$ & - & - \\
\hline & Developing Others & $.263 *$ & $.318^{*}$ & - \\
\hline & Impact and Influencing & $.254 *$ & - & - \\
\hline \multirow{2}{*}{ Managing } & Teamwork and Coordination & - & $.438 * *$ & - \\
\hline & Task Organization & $.390 * *$ & - & $.285^{*}$ \\
\hline \multirow{4}{*}{$\begin{array}{l}\text { Cognitive } \\
\text { Ability }\end{array}$} & Analytical Thinking & $.253 *$ & $.310^{*}$ & - \\
\hline & Critical Thinking & $.259 *$ & $.345^{* *}$ & - \\
\hline & Self-motivation & $.340 * *$ & $.312 *$ & $.333 * *$ \\
\hline & Self-confidence & $.385 * *$ & $.349 * *$ & $.269 *$ \\
\hline \multirow{3}{*}{ Effectiveness } & Initiative & $.254^{*}$ & $.329 * *$ & - \\
\hline & Flexibility & $.380 * *$ & $.290 *$ & $.334 * *$ \\
\hline & Assertive & $.282 *$ & $.352 * *$ & - \\
\hline \multirow{3}{*}{ Professionalism } & Commitment & - & - & - \\
\hline & Organizational Awareness & $.296^{*}$ & $.344 * *$ & $.291 *$ \\
\hline & Achievement Orientation & $.257 *$ & - & - \\
\hline
\end{tabular}

**. Correlation is significant at the 0.01 level (2-tailed).

*. Correlation is significant at the 0.05 level (2-tailed).

Kruskal-Wallis Test was conducted across the studied sustainable outcome dimensions. The statistical significance (Asymp. Sig.) presented in Table 3. Any tested data where $p>0.05$ indicates that all respondents from different grouping agreed to the same level of the studied variables. 
Table 3. K ruskal Wallis Test

\begin{tabular}{|c|c|c|c|c|}
\hline \multirow[t]{2}{*}{ Personal competence } & \multirow[t]{2}{*}{ Attribute } & $\begin{array}{l}\text { Sustainable } \\
\text { outcome } \\
\text { orientation }\end{array}$ & $\begin{array}{l}\text { Sustainable } \\
\text { outcome } \\
\text { capability } \\
\text { building } \\
\end{array}$ & $\begin{array}{l}\text { Sustainable } \\
\text { outcome } \\
\text { delivery }\end{array}$ \\
\hline & & Asymp. Sig. & Asymp. Sig. & Asymp. Sig. \\
\hline \multirow{3}{*}{ Communication } & $\begin{array}{l}\text { Interpersonal } \\
\text { understanding }\end{array}$ & 0.012 & 0.358 & 0.078 \\
\hline & $\begin{array}{l}\text { Information } \\
\text { seeking }\end{array}$ & 0.043 & 0.315 & 0.020 \\
\hline & $\begin{array}{l}\text { Stakeholder } \\
\text { orientation }\end{array}$ & 0.025 & 0.748 & 0.129 \\
\hline \multirow{4}{*}{ Leading } & Team leading & 0.092 & 0.413 & 0.426 \\
\hline & $\begin{array}{l}\text { Relationship } \\
\text { building }\end{array}$ & 0.120 & 0.374 & 0.387 \\
\hline & $\begin{array}{l}\text { Developing } \\
\text { others }\end{array}$ & 0.198 & 0.115 & 0.368 \\
\hline & $\begin{array}{l}\text { Impact and } \\
\text { influence }\end{array}$ & 0.109 & 0.308 & 0.082 \\
\hline \multirow{2}{*}{ Managing } & $\begin{array}{l}\text { Teamwork and } \\
\text { coordination }\end{array}$ & 0.494 & 0.391 & 0.641 \\
\hline & Task organization & 0.019 & 0.288 & 0.131 \\
\hline \multirow{4}{*}{ Cognitive ability } & $\begin{array}{l}\text { Analytical } \\
\text { thinking }\end{array}$ & 0.124 & 0.291 & 0.269 \\
\hline & Critical thinking & 0.229 & 0.620 & 0.306 \\
\hline & Self-motivation & 0.040 & 0.083 & 0.053 \\
\hline & Self-confidence & 0.019 & 0.055 & 0.126 \\
\hline \multirow{3}{*}{ Effectiveness } & Initiative & 0.085 & 0.335 & 0.117 \\
\hline & Flexibility & 0.029 & 0.186 & 0.063 \\
\hline & Assertive & 0.150 & 0.741 & 0.228 \\
\hline \multirow{3}{*}{ Professionalism } & Commitment & 0.509 & 0.050 & 0.194 \\
\hline & $\begin{array}{l}\text { Organizational } \\
\text { awareness }\end{array}$ & 0.087 & 0.282 & 0.114 \\
\hline & $\begin{array}{l}\text { Achievement } \\
\text { orientation }\end{array}$ & 0.139 & 0.845 & 0.199 \\
\hline
\end{tabular}

According to the results shown in Table 3, most attributes across sustainable outcome dimensions demonstrate that the respondents agreed with the correlation results presented in Table 2. A main personal competence category with the sustainable outcome orientation respondents had a different agreement on the attributes was Communication. It is evident from Table 3 that the personal communications attributes had strong significance with the sustainable outcome orientation and delivery of projects. The cognitive ability and effectiveness characteristics showed the only significant positive relationship with the suitable outcomes dimension. Whereas two of the professionalism attributes (org. awareness 
and commitment) demonstrated a significant association with the sustainable orientation and capability building dimensions.

\section{Conclusions}

This study examined the correlation between the project managers personal competencies with suitable outcomes in health development projects. The study utilised a list of 19 attributes within the six main areas of personal competence that has been defined in the Project Manager Competency Development (PMCD) framework. According to the data analysis and research findings, the study found that each of the sustainable outcome domain required different combinations of personal competence attributes. The sustainable outcome orientation is positively correlated with the communication, managing and cognitive ability competencies. The correlation analyses discovered that the personal competence areas essentially associated with the sustainable outcome orientation. The attributes of task organisation, self-motivation and confidence, flexibility and information seeking have the most robust relationship. Moreover, the domain of sustainable outcome delivery demonstrated strong associated with few attributes including information seeking, and flexibility. To validate this research results, more dimensions of project sustainable outcomes are recommended for further investigation with the PMCD framework.

\section{References}

1. T.J. Bossert, Can they get along without us? Sustainability of donor-supported health projects in Central A merica and A frica, Social Science \& Medicine 30:1015-1023 (1990)

2. Glasier, A.M. Gülmezoglu, G.P. Schmid, C.G. Moreno, P.F.A. Van Look, Sexual and reproductive health: a matter of life and death, The Lancet 368(9547):1595-1607 (2006)

3. Government of the Republic of Guinea, Project name Guinea-Population and Reproductive Health Project, M inistry of Plan, Guinea (1998)

4. P.W.G. M orris, L. Crawford, D. Hodgson, M.M. Shepherd, J. Thomas, Exploring the role of formal bodies of knowledge in defining a profession - The case of project management, International Journal of Project Management 24(8):710-721 (2006)

5. L. Crawford, A global approach to project management competence, AIPM National Conference, Gold Coast, A ustralia (1997)

6. L.H., Crawford, Project Management for Strategy Realisation, 14th W orld Congress on Project M anagement, Ljubljana, Slovenia (1998)

7. PM I, Project manager competency development framework, PM I (2017)

8. A. Swidler, S.C. W atkins, Teach a man to fish: the sustainability doctrine and its social consequences, World Development 37:1182-1196 (2009)

9. N. LaPelle, J. Zapka, J. Ockene, Sustainability of public health programs: the example of tobacco treatment services in Massachusetts, American Journal of Public Health 96:1363-1369 (2006)

10. E.G. Sarriot, P.J. Winch, L.J. Ryan, J. B owie, M. Kouletio, E. Swedberg, K. LeB an, J. Edison, R. Welch, M.C. Pacque, A methodological approach and framework for sustainability assessment in NGO-implemented primary health care programs, International Journal of Health Planning and Management 19:23-41 (2004)

11. Tango International., Sustainability of rural development projects: best practices and lessons learned by IFAD in Asia, Rome: Tango International, Rome (2009)

12. M.A. Scheirer, G. Hartling, D. Hagerman, Defining sustainability outcomes of health programs: illustrations from an on-line survey, Evaluation and Program Planning, 31: 335-346 (2008) 
13. N.C. Edwards, S.M. Roelofs, Sustainability: The elusive dimension of international heal th projects, Canadian Journal of Public Health 97:45-49 (2006)

14. D. A rgaw, M . Fanthahun, Y . B erhane, Sustainability and factors affecting the success of community-based reproductive health programs in rural Northwest Ethiopia, African Journal of Reproductive Health 11:70-79 (2007)

15. S.L. Jackson, Research methods and statistics: A critical thinking approach, Cengage L earning (2015) 